\title{
Intra-oceanic subduction shaped the assembly of Cordilleran North America
}

\author{
Authors: Karin Sigloch ${ }^{1}$, Mitchell G. Mihalynuk ${ }^{2}$
}

\begin{abstract}
Affiliations:
${ }^{1}$ Department of Earth and Environmental Sciences, Ludwig-Maximilians-Universität, Theresienstr. 41, 80333 Munich, Germany (sigloch@geophysik.uni-muenchen.de)

${ }^{2}$ British Columbia Geological Survey Branch, PO Box 9333 Stn Prov Govt, Victoria, BC, Canada, V8W 9N3 (Mitch.Mihalynuk@gov.bc.ca)
\end{abstract}

\begin{abstract}
The western quarter of North America consists of accreted terranes - crustal blocks added over the past 200 million years - but why? The widely accepted explanation posits that the oceanic Farallon plate acted as a conveyor belt, sweeping terranes into the continental margin while subducting under it. Here we show that this hypothesis, which fails to explain many terrane complexities, is also inconsistent with new tomographic images of lower-mantle slabs, and with their locations relative to plate reconstructions. We offer a radical reinterpretation of paleogeography and test it quantitatively: the seas west of Cretaceous North America must have resembled today's western Pacific, strung with island arcs. All proto-Pacific plates initially subducted into almost stationary, intra-oceanic trenches, and accumulated below as massive vertical slab walls. Above the slabs, long-lived volcanic archipelagos and subduction complexes grew. Crustal accretion occurred when North America overrode the archipelagos, causing major episodes of Cordilleran mountain building.
\end{abstract}

\section{INTRODUCTION}

Continents grow through subduction magmatism and collision of arcs and other buoyant crustal fragments at their margins. Poorly understood, such collisions are of broad scientific interest as they cause rapid geographic changes, affecting climate, ocean circulation, biota, and the formation of economically important metal deposits. North America was enlarged by a sequence of massive terrane collisions relatively recently (200-50 Ma), which created the mountainous Cordillera of the American West ${ }^{1}$.

Reconciling geological records on land with those of the ocean basins has proven difficult. Magnetic stripes on the seafloor are the basis of all quantitative plate tectonic reconstructions, and well-preserved Atlantic spreading records indicate that North America (NA) has moved 
westward continuously since the breakup of Pangaea ( $185 \mathrm{Ma})$, away from Africa and Europe ${ }^{2}$. In contrast, more than half of seafloor records of proto-Pacific (Panthalassa) ocean spreading are missing. The Pacific plate records the existence of another major oceanic plate to its northeast since at least $\sim 180 \mathrm{Ma}$, the Farallon plate. This plate is usually assumed to have filled the eastern Panthalassa basin, extending to the western NA margin and subducting under it, although this is not required by the magnetic seafloor data. Hence the Farallon plate, invoked as causative agent in practically all major land geological events since late Jurassic times ${ }^{2,3}$, should also have transported the terranes to the continental margin.

However, dozens of terranes have accreted to NA since $200 \mathrm{Ma}^{1}$, but not to the Andean margin of South America, supposedly a closely analogous setting. The terranes are mostly Triassic to Cretaceous island arc/subduction assemblages, but include three more heterogeneous superterranes, Intermontane ${ }^{4,5}$, Insular ${ }^{4}$, and Guerrero ${ }^{6}$ - essentially microcontinents. Terrane origins remain mysterious, but they formed at various latitudes and times, and pre-assembled at others, implying the temporary existence of additional oceanic plates in the northeastern protoPacific $^{7,8}$, which are missing from quantitative plate reconstructions.

The mantle retains a memory of paleo-plate configurations, in the form of subducted slabs, which seismic body-wave tomography images in situ as fast domains. Beneath NA these slab relics are massive, almost vertical walls extending from 800 to $2000 \mathrm{~km}$ in depth, and typically 400-600 km wide (fig. 1, fig S1). The largest wall runs from northwest Canada to the eastern U.S. and on to Central America: the so-called "Farallon Slab" is one of the most massive features in global tomographies ${ }^{9-12}$. We argue that it is mostly not Farallon and subdivide it into Angayucham (ANG), Mezcalera (MEZ), and Southern Farallon (SF) components (fig. 1). This reinterpretation is based our most recent tomography mode ${ }^{13}$, which utilizes dense USArray data ${ }^{14}$ in addition to global network data, using a cutting-edge waveform inversion method, multiple-frequency P-wave tomography ${ }^{13,15}$.

Besides putting the known eastern slab walls ${ }^{9-12}$ in sharper focus, we discovered ${ }^{15}$ that another, more westerly slab wall, the Cascadia Root (CR in figure 1b, depth 700-1800+ km), connects upward continuously to the present-day Cascadia trench. This makes CR a Farallon slab by definition, and prompted us to re-evaluate the "Farallon-ness" of MEZ/ANG/SF, which to our knowledge has never been questioned.

For plate reconstructions, the crucial question is how these lower-mantle slab walls have moved laterally since the slabs subducted beneath their corresponding volcanic arcs (x-y-positions in an absolute reference frame). Here we quantitatively test the hypothesis that they have not moved appreciably, i.e., vertical sinking within our observational uncertainties (a few hundred kilometers laterally). Motivated primarily by imaged slab geometries, this null-hypothesis also appears sensible in light of the Cenozoic subduction record, where absolute trench motion on average contributed only $10-30 \%$ of total plate convergence ${ }^{16,17}$. 


\section{SLABS AND ARCS AT STATIONARY TRENCHES}

Figure 2a/b shows how a steep, widened slab wall could be piled up by nearly vertical sinking beneath a long-lived, stationary trench and volcanic arc. An Andean-style west-coast trench could not have been stationary because North America moved westward as the Atlantic spread. This contradiction is resolved by westward intra-oceanic subduction prior to arrival of the continent, followed by a polarity switch of subduction to its current eastward motion into a continental-margin trench (figure 2c). Such a scenario implies that the imaged lower-mantle slabs MEZ/ANG/SF are Jurassic-Cretaceous in age, allowing collision of NA with their subduction zones to cause the Cretaceous terrane accretions.

To the extent that slabs sink vertically, they record paleo-arc and trench locations in an absolute sense. Thus vertical sinking permits quantitative predictions of the location and timing of continent-trench collisions when tomography and absolute plate reconstructions are combined. These predictions can be tested against the docking times of arc terranes inferred from land geology. Abrupt upward truncations of the slab walls, which are well resolved tomographically (fig. S2), correspond to the shutdown of the overlying trench-arc systems, and hence to docking times (figure 2).

If the trench remains stationary, a vertical slab pile is deposited beneath it. If the trench moves (but every parcel of slab sinks vertically), the imaged slab will dip toward older trench locations, assuming no dramatic lateral variations in sinking rate. The observed lower-mantle walls are widened to 400-600 km laterally, i.e., 4-6 times the thickness of oceanic lithosphere - this is not artificial blur, but the actual reason for their robust tomographic visibility ${ }^{18}$. Thickening is probably achieved by slab folding above the 670-km viscosity jump, deviations from vertical sinking being due mainly to the folding process itself (fig. 2). In convection models, slab folding occurs preferentially beneath the kind of stationary trenches postulated here ${ }^{18-20}$. Massive, thickened slabs like these can be expected to be the drivers of mantle wind, rather than blowing in it - if anything sinks vertically, it should be these slabs.

Such slab walls indicate that their overlying trenches remained in the same absolute locations for a long time, with arc and accretionary complex growth stationed above these locations Observation of massive slab walls leads us to think of their associated, intra-oceanic trenches as "terrane stations" where new crustal material is gathered to await transfer to a continental margin. Terrane stations above ANG and MEZ were not conveyed eastward into a continental Farallon trench. Rather North America migrated westward, collided, and accreted the ANG and MEZ terrane stations. Hence slab walls tie the now-displaced terranes to a laterally unchanged subsurface, constraining absolute locations and temporal evolution of oceanic trenches 100+ million years after their demise.

Figure 1 shows the reconstructed western margin of North America ${ }^{21}$, together with schematic outlines of the lower-mantle slab walls from tomography ${ }^{13}$. NA's relative westward motion is well constrained by the Atlantic spreading record ${ }^{2,22}$, independent of any absolute reference frame. Comparison to the basic geometry of ANG and MEZ suggests that these two slabs did not subduct beneath the continental margin:

(i) the slabs are vertical from 800 to $2000 \mathrm{~km}$ depth, indicating a stationary trench, whereas the margin moved westward continuously. 
(ii) the outlines of ANG and MEZ, especially the pronounced eastward promontory of MEZ, do not match the outlines of the continental margin (fig. 1). If continental subduction had controlled slab deposition, then slab curvature should reflect the curvature of the continent.

(iii) west of ANG/MEZ, the slab is smeared out laterally in the upper $800 \mathrm{~km}$ (fig. S1), as might be expected from a trench dragged along by a migrating continent: direct observational evidence for a switch in subduction mode after override, from stationary oceanic to migrating continental.

\section{QUANTITATIVE PREDICTION OF ARC ACCRETION}

Continent motions in figures 1 and 3 are tied to an absolute hotspot reference frame ${ }^{21}$ and rendered by the paleo-GIS system GPlates ${ }^{23,24}$. Like the vertically sinking slab walls, vertically rising plumes are thought not to have significant lateral motions relative to the lowermost mantle $^{25}$ (smaller deviations are correctable ${ }^{21}$ ), so that the hotspot and "slab wall” reference frames are equivalent (no relative motion). In this merged reference frame, the lateral overlay of NA's reconstructed western margin with a slab wall amounts to a spatiotemporal prediction of trench override and terrane accretion.

For example, figure 1a shows the NA margin overriding point A1, eastern promontory of the MEZ arc, at $150 \mathrm{Ma}$. Slab sinking velocities can be inferred: the shallow end of MEZ beneath A1 is seen to have sunk to $1500 \mathrm{~km}$ depth, implying an averaged sinking rate of $10 \mathrm{~mm} / \mathrm{a}$. The MEZ promontory shallows to the southwest. This is unrelated to trench polarity (the slab did not dip northeastward), but rather reflects differential sinking times (subduction at A1 was choked off earlier than at A2). Sinking rates could be estimated from any well-resolved point on the upward truncation of a slab wall, but we choose five points A1-A5 that are associated with supporting evidence from land geology (Table 1). Predicted override ages are Jurassic/Cretaceous (146-55 Ma), younging to the west, and truncation depths shallow to the west as expected. Sinking rate estimates range between 9 and $12 \mathrm{~mm} / \mathrm{a}$ ( $\pm 2 \mathrm{~mm} / \mathrm{a})$, consistent with findings of $12 \pm 3 \mathrm{~mm} / \mathrm{a}$ globally ${ }^{12}$. Fig 3 renders the override sequence in four time slices, each showing only slabs that should already have been deposited at the time, assuming the sinking rate was $10 \mathrm{~mm} / \mathrm{a}$ (average of A1-A5 in Table 1).

The Cascadia Root must be a Farallon slab because the Farallon (Juan de Fuca) plate is still subducting into it today ${ }^{15}$. Pacific seafloor records indicate continuous Farallon spreading since $\sim 180 \mathrm{Ma}^{3,26}$, so that at $10 \mathrm{~mm} / \mathrm{a}$ sinking, the 1800+ km deep Cascadia Root accounts for the entire lifetime of the (northern) Farallon plate. Presence of this CR-slab implies that the equally deep and thickened ANG-slab further east cannot represent Farallon lithosphere, as was always assumed $^{9,12,13,27,28}$. Rather, the ANG-slab must have dipped in the opposite direction (southwestward) in order to have sourced sufficient plate material from an ocean basin that lay to the northeast, the consumption of which accommodated the westward drift of North America. This scenario for transporting North America away from former Pangaea provides an alternative to westward rollback of a continental Farallon trench.

Hence our inferred trench/plate evolution in figure 3 differs radically from the commonly accepted scenario of MEZ/ANG as products of east-dipping, Farallon-beneath-continent subduction. Westward subduction of the ANG and MEZ slabs, probably since early Jurassic times, consumed the ocean that bounded North America on the west (the Angayucham and 
Mezcalera basins in fig. 3). Both basins were consumed in zipper-like fashion: Mezcalera closed from north to south, Angayucham from south to north, as NA gradually overrode and shut down the ANG/MEZ arcs between 150 and 50 Ma. Further west, the early Farallon Ocean subducted into two east-west oriented Cascadia slabs (CR/CR2), but established additional segments SF1/SF2 after a clockwise rotation at $\sim 147 \mathrm{Ma}^{22,26}$. Thus at northerly latitudes, two long-lived terrane stations of opposite polarity coexisted in ANG and CR, a variant not considered in figure 2. Upon override, the east-dipping Farallon trenches started rolling back with NA. Moderate complexities in the Pacific-Farallon spreading record ${ }^{3,26}$ probably reflect the transitions of individual trench segments from intra-oceanic to Andean-style.

\section{SUPPORTING EVIDENCE FROM LAND GEOLOGY}

We now use the terrane-station property of oceanic trench/arc systems to test archipelago override predictions made by tomography and plate reconstructions. Collision of NA with buoyant arc crust should coincide with observed deformation and accretion events.

Fig. 3b shows inferred terrane locations before override: each active trench/arc system may include a subduction complex or exotic fragments. Based on geological relationships in the present-day Cordillera ${ }^{1}$, we can match most hypothesized terranes with actual ones. ANG terranes (red) now make up interior Alaska, in fault contact with the Angayucham and related ophiolites. Alaskan workers have long inferred a southwest-dipping subduction ${ }^{29}$.

Green terranes west of A1 represent the Franciscan subduction complex of present-day California. Two superterranes from earlier subduction had already loosely accreted to NA before archipelago override began: the inboard Intermontane (IMS) ${ }^{4,5}$, and the Guerrero (GUE) to the south $^{6}$, whereas MEZ arc probably nucleated on the Insular superterrane (INS) ${ }^{4}$.

To provide for independent validation, our calibration points for sinking rates were chosen at tectonic events that are sharply defined in time and space (A1-A5 in Table 1). Events B1-B5, which are interleaved with Category A events, represent widespread Cordilleran orogenic and accretion episodes, demonstrating explanatory power on a continental scale. Four stages of override are distinguished:

Stage 1 (figures 3a/b): Beginning override of the east-verging MEZ promontory. Deformation was initially localized to the Pacific Northwest, as predicted by our model. Incipient deformation of the hinterland generated molasse that flooded the continental platform $\sim 157$ Ma between $45-55^{\circ} \mathrm{N}^{30}$. Flip in subduction direction $\sim 165 \mathrm{Ma}^{31}$ is recorded by the transition from proto-Franciscan (e.g., Red Ant formation ${ }^{32}$, orange terranes southwest of A1) to Franciscan formation (green), marking early subduction handover from MEZ to SF2.

Stage 2 (figures 3c/d): Margin-wide orogenies as NA collided with an increasingly wide swath of MEZ/SF. This caused the Sevier and Canadian Rocky Mountains orogenesis since 125 Ma. Inboard parts of IMS were partly constructed atop stable NA crust in southern California ${ }^{33}$ and had largely collapsed by $110 \mathrm{Ma}$, increasingly shedding zircons onto stable $\mathrm{NA}^{34}$, and vice versa; whereas IMS and the active Sierra Nevada arc shed zircons into the Franciscan trench ${ }^{33}$ (SF2). Intrusion of the eastward-younging Omenica magmatic belts into northern IMS and adjacent displaced North American strata ${ }^{8}$ (B1, 124-90 Ma) can be attributed to prolonged override of the MEZ promontory. 
Stage 3 (figures 3e/f): North America has entered the Farallon hemisphere. As ANG collided obliquely, its terranes (red; now interior Alaska) were accreted along the Canadian margin. Override of A3 was accompanied by a strong pulse of intermediate to basaltic volcanism, the Carmacks formation $\sim 72-69 \mathrm{Ma}^{35}$. Such high-temperature, mainly primitive volcanism arises from juxtaposition of hot, sub-slab asthenosphere after a slab, broken through arc collision (fig. 2b), has started to sink ${ }^{36}$.

The South Farallon trench was migrating westward with NA, still building the Fransciscan formation. Around A4, slab geometry indicates an outboard step from SF2 to SF3. This coincides with a strong regional pulse of ignimbrite volcanism $~ 90$ Ma (Tarahumara formation, up to $4 \mathrm{~km}$ thick and $400 \mathrm{~km}$ inland ${ }^{37,38}$ ) as the southern California/Sonora margin traverses the intermittent slab gap.

The location and timing of this trench step-back coincide almost perfectly with the inferred arrival of a buoyant oceanic Farallon plateau at the NA margin, the conjugate half of the Shatsky Rise (figure 3 includes its reconstruction by ${ }^{39}$ ). Plateau collision is a proposed mechanism ${ }^{39,40}$ for choking subduction and causing the basement uplifts of the Laramide orogeny 85-55 Ma (B3). We suggest that the event explains another first-order observation of Cordilleran geology (B4): the INS/IMS and ANG terrane packages, but not Franciscan and Guerrero, were rapidly shuffled northward along the margin between 85 and $55 \mathrm{Ma}$, by many hundreds to $>2000 \mathrm{~km}^{41}$. The convergence vector of the Farallon plate did have a large northward component at the time ${ }^{2}$, but terrane transport additionally requires strong coupling to the Farallon plate and decoupling from NA. A buoyant Farallon plateau, compressed against INS/IMS and unable to subduct, could have achieved such coupling until the trench re-established itself further west.

Stage 4 (figures 3g/h): End of archipelago override. NA overrides point A5 at 55 $\pm 7 \mathrm{Ma}$, in excellent agreement with last observed terrane accretions in the Pacific Northwest (Siletzia, Metchosin, Pacific Rim terranes $\sim 55-50 \mathrm{Ma}^{42-44}$ ). The trench stepped west (clear upward truncation at A5) as the terranes accreted, converting intra-oceanic CR into today's continental Cascadia subduction. Also 55-50 Ma, ANG was terminally overridden (B5), accompanied by explosive volcanism as the Coast Mountain arc of British Columbia shut down.

By then, slab complexity in the upper mantle rivaled today's western Pacific - not surprising given the numerous forced reorganizations. The simple depth-age relationship suggested by figure 3 need not apply to flat-lying Cenozoic slabs ${ }^{13}$ or to isolated deeper fragments like Kula or C3, since all sinking estimates were calibrated on slab walls. We do not attempt to interpret upper-mantle structure and the Cenozoic land record here, but our archipelago model provides a new framework for doing so.

\section{BETTER CONSTRAINTS ON SURFACE AND MANTLE}

Long-lived, stationary oceanic trenches explain two problematic observations, previously thought unconnected: the near-vertical geometries of the super-slabs under NA (without invoking exceptional mantle rheologies or ad-hoc shifts in absolute reference frame), and the 
long series of arc terrane accretions during Cretaceous times ${ }^{1}$ (not explained by the South American analogy).

An archipelago offshore Mesozoic North America had previously been suggested based on land geology ${ }^{7,8}$, but lacked the absolute spatial constraints provided by seismic tomography and our vertical sinking/terrane stations concept. Now-displaced terranes can be tied to their original, seismically imaged trench locations, but also to reconstructed continent locations, in an absolute reference frame. The hypothesis that continental collision with stationed terranes caused the various episodes of Cordilleran mountain building becomes testable.

Before $150 \mathrm{Ma}$, North America was located clearly too far east for MEZ/ANG to pass for continental trenches, even when longitudinal uncertainties of absolute reference frames are factored in ${ }^{45}$ (figs. 1 and S3, Tables S1, S2). The apparently "wrong” geometry and locations of the vertical slab walls - under the hypothesis of Farallon-beneath-continent subduction - had been recognized ${ }^{12,27,46,47}$ with two kinds of solutions suggested. A longitudinal shift of the global lithospheric shell relative to the lower mantle ${ }^{12}$, specifically a Cretaceous westward excursion that tapered down as the Atlantic opened, could have held NA stationary above MEZ/ANG. Alternatively, upper-mantle slab, spread out laterally by a west-coast trench, must somehow have aggregated into steep piles when transitioning into the lower mantle. This requires lateral displacements by $1000+\mathrm{km}$ of huge volumes of $\mathrm{slab}^{27,46}$. Some convection simulations have produced such behavior ${ }^{46,48}$, whereas others suggest essentially vertical sinking ${ }^{47}$, as do newer observations $^{12,13,18}$.

We showed that, within observational uncertainty limits, predicted and observed geological events are consistent. This validates simple vertical sinking and seems to explain all North American observations, including accreted terranes, but is incompatible with the widely accepted continental Farallon trench since 175+ Ma. The observed proportionality between slab depth and time since override (consistent sinking rates across all three slab walls) is not required for our argument, but rather increases confidence in its correctness.

Vertical slab sinking provides much tighter constraints on paleogeographic reconstructions than arbitrarily movable slabs. This scenario follows the principle of parsimony, so that future investigations should start with it, and seek observations requiring a departure from it. The equivalence of hotspot and "slab wall" absolute reference frames, which is implied by vertical sinking, is of great interest because slabs reach back farther in time than hotspot tracks (200+ $\mathrm{Ma}^{12,49}$ versus $\sim 130 \mathrm{Ma}^{21,22}$, and they constrain absolute paleo-longitude, which paleomagnetic data alone cannot ${ }^{50}$. However, in order to quantitatively realize a global subduction reference frame $^{12}$, it will be necessary to re-examine whether trenches commonly assumed to have been continental were not actually intra-oceanic.

\section{METHODS SUMMARY}

We postulate that subduction into all slab walls imaged tomographically beneath $\mathrm{NA}^{13}$ originated prior to the arrival of NA's western margin. Hence we must demonstrate sufficiently old slab ages, and cessation or flipping of subduction when the continent overrode the slabs. Plate 
reconstructions predict the timing of margin arrival above a slab, but only if slab ${ }^{13}$ and plate reconstructions $^{12,21,22,50-52}$ can be linked to the same absolute reference frame. Hence override predictions are correct to the extent that slab walls sank vertically, meaning that their $\mathrm{x}-\mathrm{y}$ locations since subduction are unchanged in a linked hotspot reference frame. Uncertainty is best quantified from slab wall geometry itself: deviation from vertical sinking probably did not exceed a wall's half-width (200-300 km), else such steep geometries could not have built up over a long time.

Uncertainties about absolute locations of NA's paleo-margin arise from imperfections in plate reconstructions. Due to terrane accretions and removals, there is also uncertainty about the shape and westward extent of NA's margin, compared to its present-day outlines. We discuss individual uncertainties in the SI, and propagate them into cumulative uncertainties for the times at which NA's paleo-margin overrode selected points A1-A5 on the paleo-trenches. With relative uncertainties of only 10-15\% (Tables 1, S1, S2 ), this yields the old (Jura-Cretaceous) slab ages required to support intra-oceanic subduction.

Spatiotemporal predictions of trench override are verified by terrane observations:

Override should coincide with observable collision events, since buoyant island arcs or plateaus are overridden. Uncertainties on terrane observations are difficult to quantify, but particularly characteristic events (A1-A5) can nonetheless be singled out and used successfully for validation (Table 1). Clear upward truncations of all slab walls offer direct observational evidence for continental override of oceanic trenches, and are used to calculate slab-wall sinking rates.

\section{REFERENCES}

1. Coney, P. J., Jones, D. L. \& Monger, J. W. H. Cordilleran suspect terranes. Nature (London) 288, 329333 (1980).

2. Engebretson, D. C., Cox, A. \& Gordon, R. Relative motions between oceanic and continental plates in the Pacific Basin. 206, (Geological Society of America (GSA), 1985).

3. Atwater, T. Plate tectonic history of the Northeast Pacific and western North America. (Winterer, E. L., Hussong, D. M. \& Decker, R. W.) N, 21-72 (Geol. Soc. Am., Denver, CO, United States, 1989).

4. Monger, J. W. H., Price, R. A. \& Tempelman-Kluit, D. J. Tectonic accretion and the origin of the two major metamorphic and plutonic welts in the Canadian Cordillera. Geology 10, 70-75 (1982).

5. Mihalynuk, M. G., Nelson, J. \& Diakow, L. J. Cache Creek Terrane entrapment: Oroclinal paradox within the Canadian Cordillera. Tectonics 13, 575-595 (1994).

6. Dickinson, W. R. \& Lawton, T. F. Carboniferous to Cretaceous assembly and fragmentation of Mexico. Geological Society of America Bulletin 113, 1142-1160 (2001).

7. Moores, E. M. Ophiolites, the Sierra Nevada, 'Cordilleria,' and orogeny along the Pacific and Caribbean margins of North and South America. International Geology Review 40, 40-54 (1998).

8. Johnston, S. T. The great Alaskan terrane wreck; reconciliation of paleomagnetic and geological data in the northern Cordillera. Earth and Planetary Science Letters 193, 259-272 (2001).

9. Grand, S. P., Van der Hilst, R. D. \& Widiyantoro, S. Global seismic tomography; a snapshot of convection in the Earth. GSA Today 7, 1-7 (1997). 
10. Montelli, R., Nolet, G., Masters, G., Dahlen, F. A. \& Hung, S.-H. Global P and PP traveltime tomography: rays versus waves. Geophysical Journal International 158, 637-654 (2004).

11. Li, C., Van der Hilst, R. D., Engdahl, E. R. \& Burdick, S. A new global model for P wave speed variations in Earth's mantle. Geochemistry, Geophysics, Geosystems 9, 05018 (2008).

12. Van der Meer, D. G., Spakman, W., Van Hinsbergen, D. J. J., Amaru, M. L. \& Torsvik, T. H. Towards absolute plate motions constrained by lower-mantle slab remnants. Nature Geoscience 3, 36-40 (2010).

13. Sigloch, K. Mantle provinces under North America from multifrequency P wave tomography. Geochemistry, Geophysics, Geosystems 12, (2011).

14. Pavlis, G. L., Sigloch, K., Burdick, S., Fouch, M. J. \& Vernon, F. L. Unraveling the geometry of the Farallon plate: Synthesis of three-dimensional imaging results from USArray. Tectonophysics 532, 82-102 (2012).

15. Sigloch, K., McQuarrie, N. \& Nolet, G. Two-stage subduction history under North America inferred from multiple-frequency tomography. Nature Geoscience 1, 458-462 (2008).

16. Sdrolias, M. \& Müller, R. D. Controls on back-arc basin formation. Geochemistry, Geophysics, Geosystems 7, 04016 (2006).

17. Goes, S., Capitanio, F. A., Morra, G., Seton, M. \& Giardini, D. Signatures of downgoing platebuoyancy driven subduction in Cenozoic plate motions. Physics of the Earth and Planetary Interiors 184, 1-13 (2011).

18. Ribe, N. M., Stutzmann, E., Ren, Y. \& Van der Hilst, R. Buckling instabilities of subducted lithosphere beneath the transition zone. Earth and Planetary Science Letters 254, 173-179 (2007).

19. Gibert, G., Gerbault, M., Hassani, R. \& Tric, E. Dependency of slab geometry on absolute velocities and conditions for cyclicity: insights from numerical modelling. Geophysical Journal International 189, 747-760 (2012).

20. Goes, S., Capitanio, F. A. \& Morra, G. Evidence of lower-mantle slab penetration phases in plate motions. Nature (London) 451, 981-984 (2008).

21. O'Neill, C., Müller, D. \& Steinberger, B. On the uncertainties in hot spot reconstructions and the significance of moving hot spot reference frames. Geochemistry, Geophysics, Geosystems 6, 04003 (2005).

22. Seton, M. et al. Global continental and ocean basin reconstructions since 200 Ma. Earth-Science Reviews 113, 212-270 (2012).

23. Boyden, J. A. et al.in Geoinformatics: Cyberinfrastructure for the Solid Earth Sciences (Cambridge University Press, 2012).

24. Gurnis, M. et al. Plate tectonic reconstructions with continuously closing plates. Computers and Geosciences 38, 35-42 (2012).

25. Morgan, W. J. Convection Plumes in the Lower Mantle. Nature 230, 42-43 (1971).

26. Sager, W. W., Handschumacher, D. W., Hilde, T. W. C. \& Bracey, D. R. Tectonic evolution of the northern Pacific plate and Pacific-Farallon Izanagi triple junction in the Late Jurassic and Early Cretaceous (M21-M10). Tectonophysics 155, 345-364 (1988).

27. Bunge, H.-P. \& Grand, S. P. Mesozoic plate-motion history below the northeast Pacific Ocean from seismic images of the subducted Farallon slab. Nature 405, 337-340 (2000).

28. Ren, Y., Stutzmann, E., Hilst, R. D. van der \& Besse, J. Understanding seismic heterogeneities in the lower mantle beneath the Americas from seismic tomography and plate tectonic history. Journal of Geophysical Research 112, 1-15 (2007).

29. Decker, J. et al. Geology of Southwestern Alaska. (Plafker, G. \& Berg, H. C.) G-1, 285-310 (Geological Society of America, Boulder, CO, United States, 1994). 
30. Poulton, T. P. et al. Kootenay/Nikanassin/Minnes/Deville/ Success Isopach and Lithofacies, in The Geological Atlas of the Western Canada Sedimentary Basin, Chapter 18. (2013).at <www.ags.gov.ab.ca/publications/abstracts/DIG_2008_0252.html>

31. Saha, A., Basu, A. R., Wakabayashi, J. \& Wortman, G. L. Geochemical Evidence for a Subducted Infant Arc in Franciscan High-Grade-Metamorphic Tectonic Blocks. Geological Society of America Bulletin 117, 1318-1335 (2005).

32. Dickinson, W. R. Accretionary Mesozoic-Cenozoic expansion of the Cordilleran continental margin in California and adjacent Oregon. Geosphere 4, 329-353 (2008).

33. Ernst, W. G. Accretion of the Franciscan Complex attending Jurassic-Cretaceous geotectonic development of northern and central California. Bulletin of the Geological Society of America 123, 1667-1678 (2011).

34. Leier, A. L. \& Gehrels, G. E. Continental-scale detrital zircon provenance signatures in Lower Cretaceous strata, western North America. Geology 39, 399-402 (2011).

35. Johnston, S. T. et al. Yellowstone in Yukon: The Late Cretaceous Carmacks Group. Geology 24, 9971000 (1996).

36. Van de Zedde, D. M. A. \& Wortel, M. J. R. Shallow slab detachment as a transient source of heat at midlithospheric depths. Tectonics 20, 868-882 (2001).

37. McDowell, F. W., Roldan-Quintana, J. \& Connelly, J. N. Duration of Late Cretaceous-early Tertiary magmatism in east-central Sonora, Mexico. Geological Society of America Bulletin 113, 521-531 (2001).

38. Gonzalez-Leon, C. M. et al. Stratigraphy, geochronology, and geochemistry of the Laramide magmatic arc in north-central Sonora, Mexico. Geosphere 7, 1392-1418 (2011).

39. Liu, L. et al. The role of oceanic plateau subduction in the Laramide orogeny. Nature Geoscience 3, 353-357 (2010).

40. Livaccari, R. F., Burke, K. \& Sengor, A. M. C. Was the Laramide Orogeny related to subduction of an oceanic plateau? Nature (London) 289, 276-278 (1981).

41. Enkin, R. J., Mahoney, J. B., Baker, J., Riesterer, J. \& Haskin, M. L. Deciphering shallow paleomagnetic inclinations: 2. Implications from Late Cretaceous strata overlapping the Insular/Intermontane Superterrane boundary in the southern Canadian Cordillera. Journal of Geophysical Research B: Solid Earth 108, EPM 4-1 - 4-19 (2003).

42. Massey, N. Metchosin Igneous Complex, Southern Vancouver Island - Ophiolite Stratigraphy Developed in an Emergent Island Setting. Geology 14, 602-605 (1986).

43. Wells, R. E. Reconsidering the origin and emplacement of Siletzia. Abstracts with Programs Geological Society of America 39, 19 (2007).

44. Schmandt, B. \& Humphreys, E. Seismically imaged relict slab from the $55 \mathrm{Ma}$ Siletzia accretion to the northwest United States. Geology 39, 175-178 (2011).

45. Shephard, G. E. et al. Testing absolute plate reference frames and the implications for the generation of geodynamic mantle heterogeneity structure. Earth and Planetary Science Letters 317318, 204-217 (2012).

46. Liu, L., Spasojević, S. \& Gurnis, M. Reconstructing Farallon Plate Subduction Beneath North America Back to the Late Cretaceous. Science 322, 934-938 (2008).

47. Steinberger, B., Torsvik, T. H. \& Becker, T. W. Subduction to the lower mantle - a comparison between geodynamic and tomographic models. Solid Earth Discussions 4, 851-887 (2012).

48. Zhong, S. \& Gurnis, M. Mantle Convection with Plates and Mobile, Faulted Plate Margins. Science 267, 838-843 (1995). 
49. Meer, D. G. van der, Torsvik, T. H., Spakman, W., Hinsbergen, D. J. J. van \& Amaru, M. L. IntraPanthalassa Ocean subduction zones revealed by fossil arcs and mantle structure. Nature Geoscience (2012).doi:10.1038/ngeo1401

50. Torsvik, T. H., Müller, R. D., Van der Voo, R., Steinberger, B. \& Gaina, C. Global plate motion frames: Toward a unified model. Reviews of Geophysics 46, 3004 (2008).

51. Müller, R. D., Royer, J.-Y. \& Lawver, L. A. Revised plate motions relative to the hotspots from combined Atlantic and Indian Ocean hotspot tracks. Geology 21, 275-278 (1993).

52. Steinberger, B. \& Torsvik, T. H. Absolute plate motions and true polar wander in the absence of hotspot tracks. Nature 452, 620-623 (2008).

\section{ACKNOWLEDGEMENTS}

We thank Dietmar Müller for making available the plate reconstructions of ${ }^{22}$ before publication (for fig. 1), as well as the Shatsky plateau reconstructions of ${ }^{39}$ for fig. 3. Thank you to Gary W. Ernst and two anonymous referees for their thorough, constructive reviews. The P-wave tomography model used here is available in ASCII format as part of the Auxiliary Materials for 13 at www.agu.org/journals/gc/gc1102/2010GC003421/supplement.shtml, or may be obtained from K.S. This is BC Geological Survey Branch contribution \#2012-2.

\section{AUTHOR INFORMATION}

K.S. generated the tomographic model, and integrated it with quantitative plate tectonic reconstructions in GPlates. M.G.M. provided the geological background and made the terrane maps of fig. 3. Both authors contributed equally to developing the tectonic arguments and to the writing. The authors declare no competing financial interests. Correspondence and requests for materials should be addressed to K.S. (sigloch@geophysik.uni-muenchen.de) or M.G.M.

(Mitch.Mihalynuk@gov.bc.ca) 


\begin{tabular}{|c|c|c|c|c|c|}
\hline Event & $\begin{array}{l}\text { Geometric/kinematic } \\
\text { event description }\end{array}$ & $\begin{array}{l}\text { Matched geological validation } \\
\text { event (timing in Ma) }\end{array}$ & $\begin{array}{c}\text { Reconstr } \\
\text { ucted } \\
\text { time t } \\
\text { (Ma) } \\
\end{array}$ & $\begin{array}{c}\text { Slab depth } \\
\text { d (km) }\end{array}$ & $\begin{array}{l}\text { Slab sinking } \\
\text { velocity v } \\
(\mathbf{m m} / \mathbf{a})\end{array}$ \\
\hline A1 & $\begin{array}{l}\text { Start override of MEZ } \\
\text { promontory. } \\
\text { Overridden segment gets } \\
\text { replaced by incipient South } \\
\text { Farallon trench SF2. }\end{array}$ & $\begin{array}{c}\text { Initiation of Rocky Mtn deformation, } \\
\text { recorded by synorogenic clastic } \\
\text { wedge (160-155). Initiation of } \\
\text { Franciscan subduction complex/S. } \\
\text { Farallon (165-155). }\end{array}$ & $146 \pm 24$ & $1500 \pm 100$ & $10 \pm 2$ \\
\hline B1 & $\begin{array}{l}\text { Gradual override of MEZ } \\
\text { promontory by NA (Pacific } \\
\text { Northwest). }\end{array}$ & $\begin{array}{l}\text { Omenica magmatic belts in Pacific } \\
\text { Northwest (124-90). }\end{array}$ & - & - & - \\
\hline A2 & $\begin{array}{l}\text { End override of MEZ } \\
\text { promontory (shallowest } \\
\text { point of slab wall). }\end{array}$ & - & $111 \pm 8$ & $1050 \pm 50$ & $9 \pm 1$ \\
\hline B2 & $\begin{array}{l}\text { Widening collision of NA } \\
\text { margin with archipelago } \\
\text { (MEZ/ANG/SF arcs). }\end{array}$ & $\begin{array}{l}\text { Margin-wide strong deformation: } \\
\text { Sevier and Canadian Rocky } \\
\text { Mountains (since 125). }\end{array}$ & - & - & - \\
\hline A3 & $\begin{array}{l}\text { Override of ANG arc, } \\
\text { followed by slab window. }\end{array}$ & $\begin{array}{c}\text { Carmacks volcanic episode due to } \\
\text { slab window (72-69). }\end{array}$ & $74 \pm 7$ & $850 \pm 50$ & $12 \pm 1$ \\
\hline A4 & \begin{tabular}{|l} 
S. Farallon trench steps \\
westward after accretion of \\
Shatsky Conjugate plateau.
\end{tabular} & $\begin{array}{c}\text { Sonora volcanism due to slab } \\
\text { window: Tarahumara ignimbrite } \\
\text { province }(85 \pm 5) \text {. }\end{array}$ & $88 \pm 3$ & $800 \pm 50$ & $9 \pm 1$ \\
\hline B3 & \multirow{2}{*}{$\begin{array}{l}\text { Strong transpressive } \\
\text { coupling of Farallon plate } \\
\text { to superterranes as buoyant } \\
\text { Shatsky conj. subducts. }\end{array}$} & $\begin{array}{l}\text { Laramide orogeny, basement uplift } \\
1000+\text { km inland (85-55). }\end{array}$ & - & - & - \\
\hline B4 & & $\begin{array}{l}\text { Northward shuffle of INS, IMS, and } \\
\text { ANG terranes along margin (85-55). }\end{array}$ & - & - & - \\
\hline A5 & $\begin{array}{l}\text { Override of CR arc by } \\
\text { Pacific NW U.S. }\end{array}$ & $\begin{array}{l}\text { Last terrane accretions: Siletzia, } \\
\text { Pacific Rim (55-50). }\end{array}$ & $55 \pm 7$ & $600 \pm 30$ & $12 \pm 2$ \\
\hline B5 & $\begin{array}{l}\text { Final override of } \\
\text { westernmost ANG. }\end{array}$ & $\begin{array}{l}\text { Explosive end of Coast Belt arc } \\
\text { volcanism (55-50). }\end{array}$ & - & - & - \\
\hline
\end{tabular}

Table 1: Sequence of archipelago override. Column 2 describes tectonic events in terms of geometrically predicted slab/margin interactions. Column 3 describes matching events from the land geological record. For well-localized events (A1-A5), we estimate slab depth d, time t since last subduction (margin override), and slab sinking rate $\mathrm{v}$, from the tomographic and plate models. Calculations are explained in Methods; for uncertainty analysis see SI. Geologically observed timing does not enter the calculations, since the role of the geological events is to validate the geometrically inferred results. Events B1-B5 represent additional, first-order tectonic episodes explained by the scenario of archipelago override (these are not localized enough spatiotemporally to derive sinking rates). 

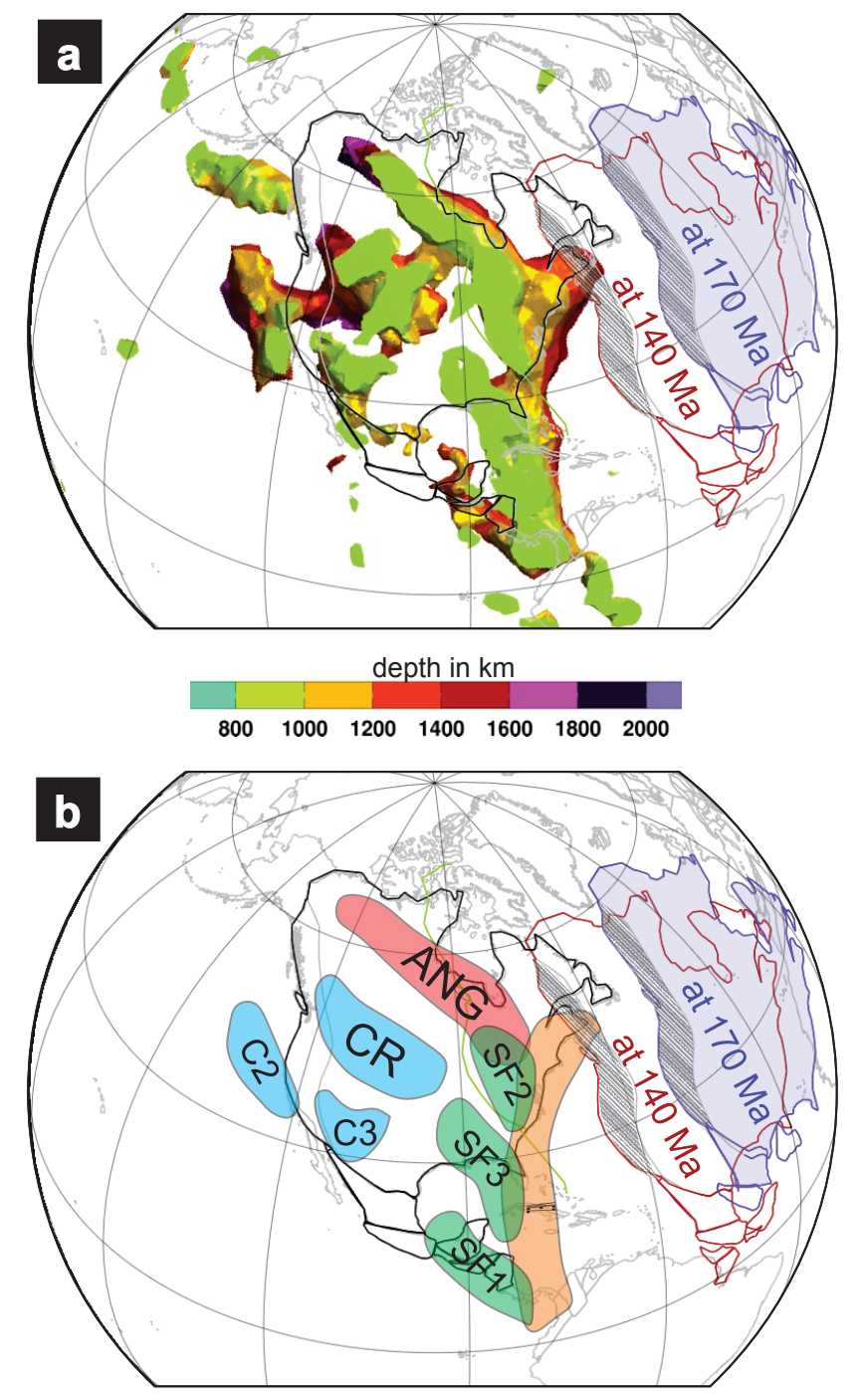

Figure 1 

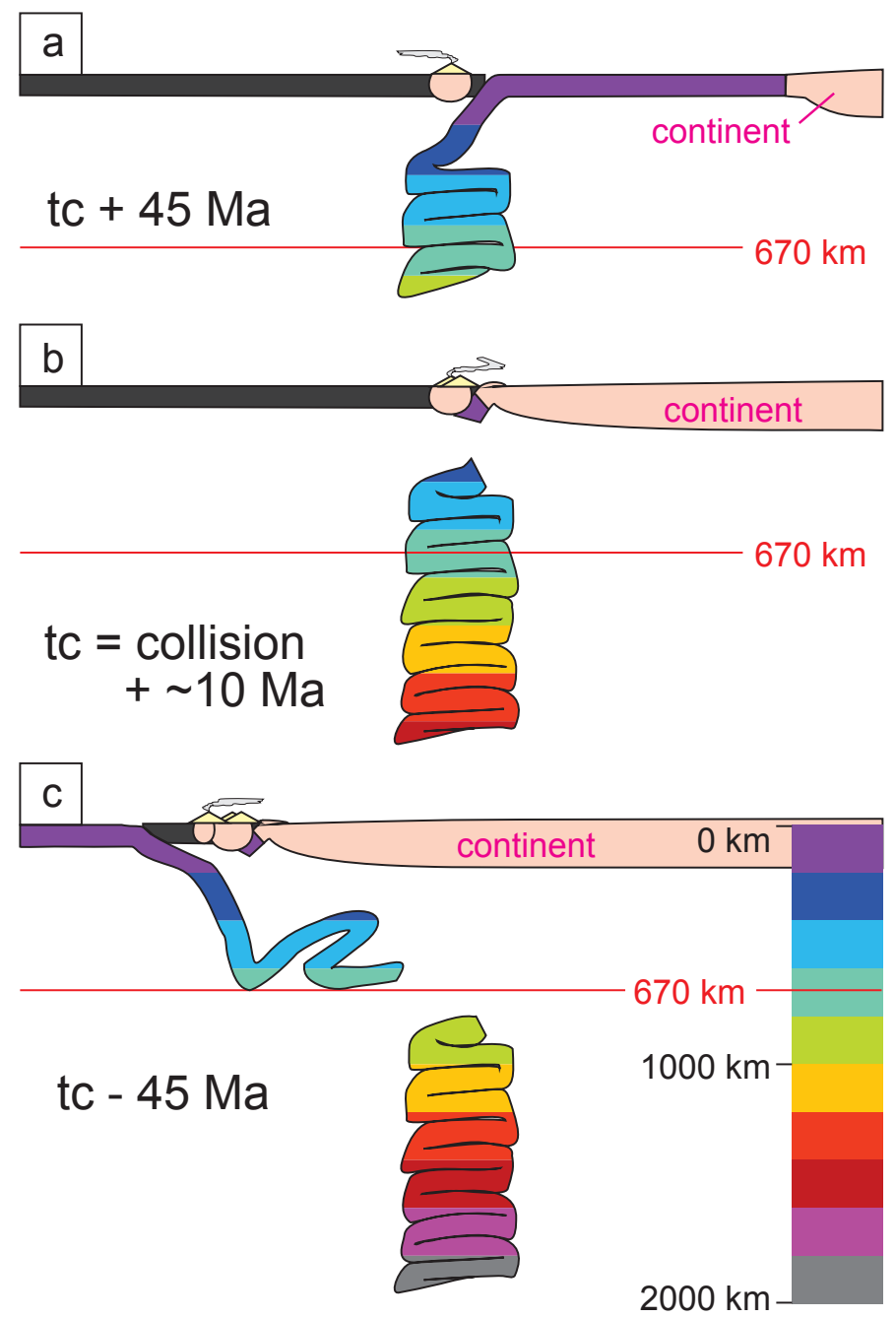

Figure 2 

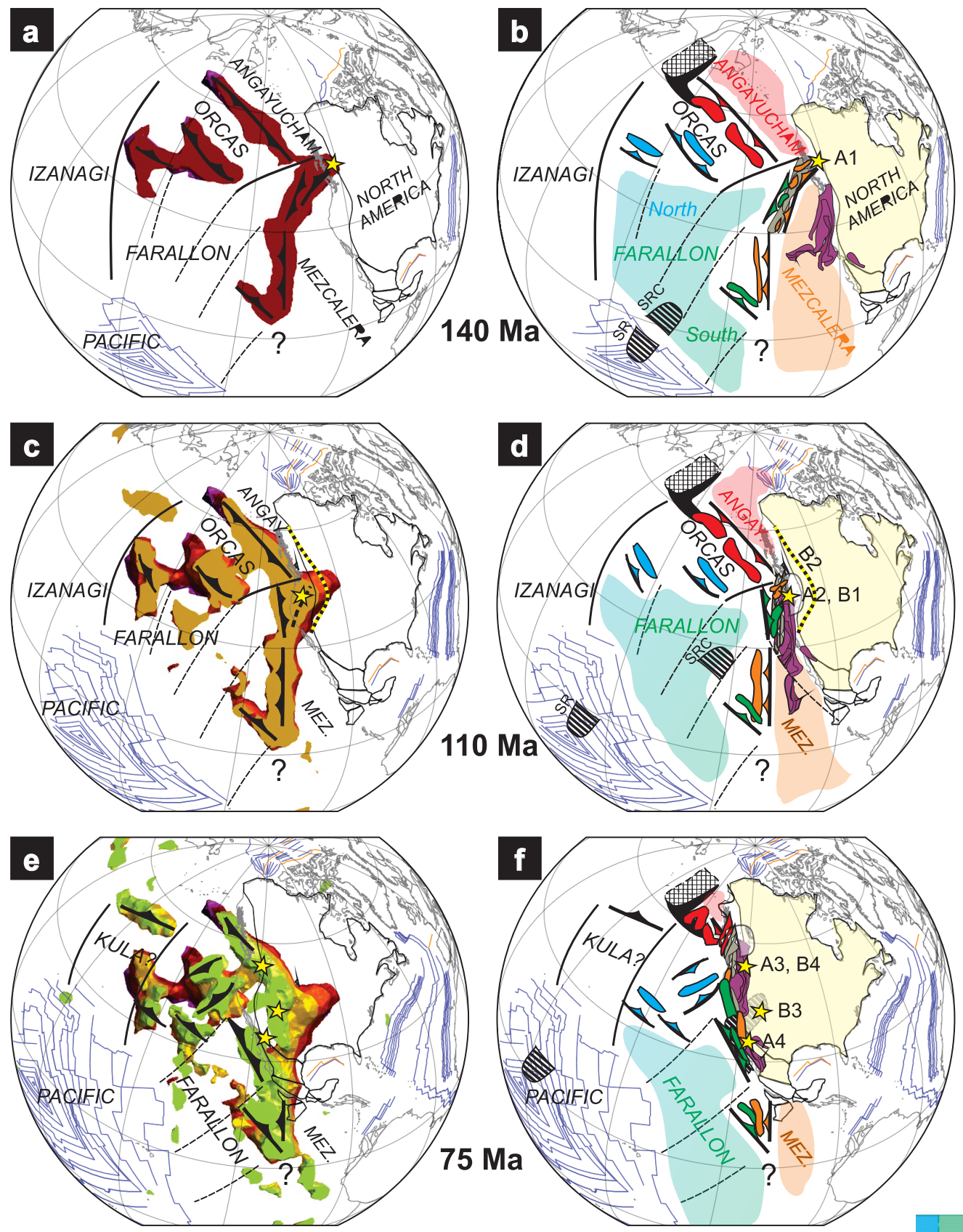

Arcs above imaged slabs

(Early Jurassic and younger)

Angayucham

(now interior Alaska)

$\checkmark$ Mezcalera

(younger Guerrero)

5 Cascadia/N. Farallon

(e.g., Siletzia)

Southern Farallon
(e.g., Franciscan)

IIII Shatsky Rise and Shatsky Rise Conjugate

\section{Older terranes}

(older than mid-Jurassic)

Intermontane superterrane (IMS)

Insular superterrane (INS)

(Wrangellia-Alexander)

Arctic Alaska - Seward

Angayucham plateau

\section{Other features}

is geological marker event

active ridge/transform

$\therefore \quad$ fracture zone

? area tomographically unresolved
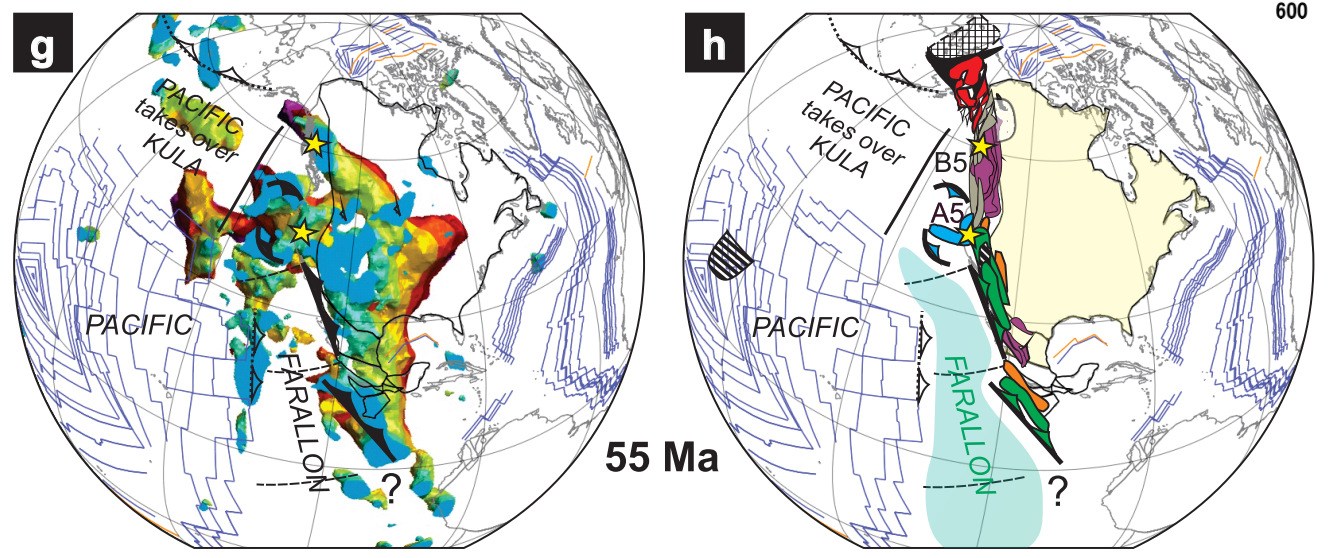

$\begin{array}{llllllll}600 & 800 & 1000 & 1200 & 1400 & 1600 & 1800 & 2000\end{array}$ depth in $\mathrm{km}$

Figure 3 


\section{Figure legends}

Fig. 1. Slabs under North America and continental motion over time. a: Subducted slabs at and below $900 \mathrm{~km}$ depth. P-wave tomography model ${ }^{13}$ rendered as 3-D isosurface contours, which enclose faster-than-average structure (threshold $\mathrm{dVp} / \mathrm{Vp}=0.25 \%$ ). Color signifies depth and changes every $200 \mathrm{~km}$; the scene is illuminated to convey 3-D perspective. At a sinking rate of $\sim 10 \mathrm{~mm} / \mathrm{a}$, this slab assemblage should have been deposited from 200 Ma to $90 \mathrm{Ma}$. Reconstructed continent positions at $140 \mathrm{Ma}$ in a hotspot reference frame ${ }^{21}$ and at $170 \mathrm{Ma}$ in a hybrid frame ${ }^{22}$. Hatched: location uncertainty for continental margin during Jurassic/Cretaceous times. Cross-hatched: terranes that accreted during Cretaceous and early Tertiary times. b: Interpretative legend. The slab walls divide into four groups: Cascadia/Northern Farallon slabs (blue) and Southern Farallon slabs (green), due to eastward subduction; Angayucham (ANG, red) and Mezcalera (MEZ, orange) slabs, due to westward subduction. Before $140 \mathrm{Ma}$, sizeable ocean basins separated North America from the ANG/MEZ trenches.

Fig. 2. Schematic cross-section and evolution of a terrane station. $t_{c}$ denotes time of arc-continent collision $+\sim 10$ Ma. Vertical line is fixed in a lower-mantle reference frame; same depth coloring as in figures 1a and 3. a: time $=t_{c}-45 \mathrm{Ma}$; trench and arc are active. Slab buckling is due to viscosity contrast around $670 \mathrm{~km}$, but backlog reaches into upper mantle. $\mathrm{b}$ : time $=\mathrm{t}_{\mathrm{c}}$; continent overrides trench and accretes its arc, while slab breaks. c: time $=\mathrm{t}_{\mathrm{c}}+45 \mathrm{Ma}$; slab wall continues to sink. Seaward, a new, Andean-style subduction has developed. Anchored in the lower mantle, the slab wall is sinking vertically at a steady-state rate of $\sim 10 \mathrm{~mm} / \mathrm{a}$ in all three panels.

Fig. 3. Sequence of trench overrides and terrane accretions. First column shows time-depth slices at $\mathrm{t}=140,110,75$, and $55 \mathrm{Ma}$; tomography model and plate reconstructions rendered as in figure 1. Each slice shows only material that should have been deposited by that time, i.e., slab at and below a depth of $v^{\bullet} t$, where $\mathrm{v}=10 \mathrm{~mm} / \mathrm{a}$ is the assumed sinking rate. All slabs are colored according to their current depths, but mentally their upper truncations should be migrated up to the surface, representing the inferred active arc locations at each time. The 140-Ma slice renders slab at and below $1500 \mathrm{~km} ; 110 \mathrm{Ma} \rightarrow 1200 \mathrm{~km} ; 75 \mathrm{Ma} \rightarrow 800 \mathrm{~km} ; 55 \mathrm{Ma} \rightarrow 600 \mathrm{~km}$. Associated maps in second column are interpretative cartoons showing the evolution of inferred trench and terrane geometries. Stars mark tectonic events of Table 1. 


\section{METHODS}

The Mezcalera/Angayucham slab walls have been among the most robust features in global-scale body-wave tomography, starting with the work of Grand ${ }^{9-13,28}$. The deep end of the Cascadia Root slab was already visible in some of the earlier studies. Its continuous upward connection to present-day Cascadia subduction was pointed out by Sigloch $20088^{15}$, hence its identification as a Farallon slab. The model on which we base our discussion here ${ }^{13}$ is an inversion of P-wave observations recorded by North American broadband stations, using a cutting-edge waveform inversion technique (multi-frequency tomography) on a global, adaptive grid. Method discussion and formal resolution tests are presented in ${ }^{13}$. The higher resolution compared to global tomography models is largely due to densely spaced stations from the USArray experiment in the western half of the U.S., and waveforms recorded 2005-2008, which were not included in any of the above global models. Our calibration points for sinking rate, especially A3-A5, lie within the mantle subvolume that considerably benefits from resolution improvements afforded by the new USArray data.

We postulate that subduction into all slab walls imaged tomographically beneath $\mathrm{NA}^{13}$ originated prior to the arrival of NA's western margin. Hence we must demonstrate sufficiently old slab ages, and cessation or flipping of subduction when the continent overrode the slabs. Plate reconstructions predict the timing of margin arrival above a slab, but only if slab and plate reconstructions ${ }^{12,21,22,50-52}$ can be linked to the same absolute reference frame. (Technically we accomplish this with the free community paleo-GIS GPlates ${ }^{23,24}$ and a compilation of digitally published reference frames ${ }^{45}$.) Hence override predictions are correct to the extent that slab walls sank vertically, meaning that their $x-y$ locations since subduction are unchanged in a linked hotspot reference frame. Uncertainty is best quantified from slab wall geometry itself: deviation from vertical sinking probably did not exceed a wall's half-width (200-300 km), else such steep geometries could not have built up over a long time.

Uncertainties about absolute locations of NA's paleo-margin arise from imperfections in plate reconstructions. Due to terrane accretions and removals, there is also uncertainty about the shape and westward extent of NA's margin, compared to its present-day outlines. We discuss individual uncertainties in the SI, and propagate them into cumulative uncertainties for the times at which NA's paleo-margin overrode selected points A1-A5 on the paleo-trenches. With relative uncertainties of only 10-15\% (Tables 1, S1, S2), this yields the old (Jura-Cretaceous) slab ages required to support intra-oceanic subduction.

Spatiotemporal predictions of trench override are verified by terrane observations:

Override should coincide with observable collision events, since buoyant island arcs or plateaus are overridden. Uncertainties on terrane observations are difficult to quantify, but particularly characteristic events (A1-A5) can nonetheless be singled out and used successfully for validation (Table 1). Sinking rate calculations provide an additional plausibility check. Consistent results of 9-12 $\mathrm{mm} / \mathrm{a}( \pm 1-2 \mathrm{~mm} / \mathrm{a})$ across all three slab walls show that this type of feature seems to sink rather predictably and evenly. If this is the case, then conversely the override prediction times that lead to the rate estimates should be adequate. 
Sinking at $\sim 10 \mathrm{~mm} / \mathrm{a}$ is considered a lower-mantle sinking rate, but we obtain it as an average over upper and lower mantle. This is explained if a wall sank in steady state: upon subduction of its youngest end (figure 2b), its lower part had already entered the viscous lower mantle and was setting the speed limit from below, which acted on the entire pile. Such a wall, widened to 4-6 times lithospheric thickness (400-600 km), and sinking at $\sim 10 \mathrm{~mm} / \mathrm{a}$, generates the same material throughput as the typical $40-60 \mathrm{~mm} / \mathrm{a}$ of unbuckled plate convergence in the uppermost mantle ${ }^{16,20}$ - a plausibility check confirming continuity of upper and lower mantle fluxes.

Sinking rates are obtained by dividing the imaged depth of a wall's shallowest end (depth reached since end of subduction) by predicted time since trench override. Besides timing uncertainty, a spatial uncertainty about the slab's true depth enters, as discussed quantitatively in SI (figure S2). These uncertainties are comparatively small, because upward truncations of the slab walls are sharply imaged. This is also a striking visual feature, e.g., in figure 3g or figure S2: along their lengths, MEZ and ANG show abrupt upward truncations in red to orange, yellow and green depth levels. This provides direct observational evidence for westward subduction - after trench override, there was no slab left to subduct. By contrast, the less complete upward truncation of eastward-dipping CR around A5 (cyan color level, a more localized slab window) indicates "only" a larger terrane accretion event and trench step-back when the margin transitioned from intra-oceanic to Andean. Upward truncations shallow to the west (A1 at red level, A2 yellow, A3/A4 green, A5 cyan), reflecting more and more recent ages for termination of subduction.

In summary, the observational uncertainties that enter, and that we discuss in SI, are:

1) Uncertainties in plate reconstructions at the surface: When exactly did the North American paleo-margin overlie a given point in the reference frame, e.g., A1-A5? This includes relative reconstruction uncertainties (essentially ambiguities about Atlantic opening; they are small, and neglected in our calculations); uncertainties about absolute reference frame (considerable; we attempt to quantify them by comparing different reference frames ${ }^{12,21,22,45,50-52}$ (figure S3); and uncertainties about the true westward extent of the paleo-margin over time. The latter uncertainty is most difficult to quantify, since it requires knowledge about accreted terrane locations, which shifted over time. Our best guess of the uncertain area's extent is hatched in figures $1 \mathrm{a} / \mathrm{b}$ and $\mathrm{S} 3 \mathrm{a} / \mathrm{b}$. Margin uncertainty is the biggest contributor to reconstruction uncertainties (typically 6-7 $\mathrm{Ma}$ ), except for the oldest point $\mathrm{A} 1$, where absolute reference frame uncertainty dominates (Table S2).

2) Uncertainties in paleo-trench locations, relative to the slab: Were trench points A1-A5 centered on the imaged slab walls, systematically offset to one side, or oscillating? We assume that the trenches ran centered, for lack of evidence to the contrary. A constant offset would hardly change the calculations, producing a strong correlation with margin uncertainty rather than independent uncertainties. Periodic trench advance and retreat - as buckling folds are being laid down - cannot be excluded, but we are unaware of observational evidence. Unless these oscillations significantly exceeded the half-width of the slab wall of 200-300 km (unlikely, given the tall slab piles), they would not dominate over margin uncertainty. 
3) Uncertainties about present-day slab depth (pertinent only to sinking rate estimates). Evaluation of tomographic blur yields significantly smaller relative uncertainties than reconstruction errors (Table S1). The two types of relative errors enter symmetrically into cumulative uncertainty on sinking rate.

Regarding our hypothesis of intra-oceanic trenches, the most important, qualitative assessment of uncertainty is this: all plate reconstructions considered ${ }^{21,22,45,50-52}$ (with one exception ${ }^{12}$ discussed below) agree that two ocean basins should have existed between North America and the Mezcalera/Angayucham slabs before $140 \mathrm{Ma}$ (figure 1a and figure S3a). These oceans were considerably wider than the uncertainty in margin extent, implying intra-oceanic subduction origins for all imaged slab walls, provided they are older than $140 \mathrm{Ma}$. That this is the case is shown by good agreement between predicted and geologically observed collision events (within the moderate error bars of Table 1). An extrapolation of sinking rates of $\sim 10 \mathrm{~mm} / \mathrm{a}$ to the lower ends of the slab walls at 1800+ km depth implies that subduction originated at least $180 \mathrm{Ma}$ ago.

The one reference frame ${ }^{12}$ that does not predict wide Angayucham/Mezcalera ocean basins in the late Jurassic/early Cretaceous was explicitly designed to minimize their extents, by imposing a constraint that keeps NA's western margin stationary above the MEZ/ANG slabs (i.e., an Andean-style margin is enforced a priori, figure S3b). This is accomplished by introducing an additional degree of freedom, an ad-hoc, otherwise non-observable, westward shift of the lithospheric shell relative to the lower mantle. In solving for this longitudinal shift, the method considers a global slab inventory, but for the times discussed here, the influence of the MEZ/ANG slabs dominates. Hence this reference frame does not lend itself to evaluating the existence of the Angayucham/Mezcalera oceans. 